\title{
CONTROLLING OF INSECT-PARASITES OF ALFALFA LEAFCUTTING BEESTOCK (MEGACHILE ROTUNDATA F., HYMENOPTERA, MEGACHILIDAE)
}

\author{
Jenö FARKAS and László SZALAY \\ with the technical collaboration of Zoltán TISZAI \\ Research Centre for Animal Breeding and Nutrition \\ H-2100 Gödölló, P.O.B. 57, Hungary
}

\section{SUMMARY}

Many millions of Megachile rotundata (Fabricius) prepupae were imported from the USA to Hungary between 1972 and 1978, but the general introduction of alfalfa leafcutting bee to Hungary planned for 1974 and 1975 could not be realized because of the heavy infestation by parasites.

In 1981 we determined the Melitobia acasta Walker infestation of cocoons left behind by emerged alfalfa leafcutting bees. In 1982 we counted all the parasites emerged during the incubation period.

In 1981 after the completion of incubation one male leafcutting bee and 4913 Chalcidoidea emerged from the 1200 leafcutting bee cocoons during 50 days; they died without food within 10-14 days.

Melittobia acasta Walker chosen randomly run towards day-light with a velocity of $9-14 \mathrm{~m} / \mathrm{h}$.

In 1982 the number of emerged Megachile and Coelioxys increased by keeping the cocoons at lower temperatures and by treatment with Sevin, while the number of emerged Melittobia decreased.

Besides the usual measurements new technological and management methods are needed in order to control the parasites.

\section{INTRODUCTION}

The alfalfa leafcutting bee, Megachile rotundata (Fabricius) has become one of the world's most important pollinators of alfalfa. Most alfalfa seed growers who use this bee have substantially higher seed yields than those who rely on native pollination. Several bee species, including bumble bees and native leafcutting bees are efficient pollinators, but their populations fluctuate from year to year or even 
decrease as nesting habitats are reduced or destroyed by modern agricultural practices.

According to our knowledge today the mass use of alfalfa leafcutting bees is the only way to obtain large-scale alfalfa seed production (BOHART, 1962 ; Hobbs, 1968 ; Holm, 1982 ; Krunic and Hinks, 1972 ; Morgner, 1973 ; RanK et al., 1981 ; Richards, 1982 ; STEPHEN, 1961).

There are several testing centers in the United States and Canada, where samples submitted by beekeepers are controlled by the method of STEPHEN and UNDURRAGa (1976). This control method takes first of all the quality and parasitism of bees into consideration.

The native population of Megachile rotundata is small in Hungary (MóczÁr and Böjtös, 1957).

Between 1972 and 1978 several millions of prepupae were imported from the United States and Canada to Hungary. Nevertheless, the general use of alfalfa leafcutting bees for alfalfa seed growing (MANNINGER, 1970) planned for 1974-1975 could not be realized. The main reason for the failure was the heavy parasitism of the stock.

This situation induced us to investigate the possibilities of artificial propagation and methods for controlling parasites of the alfalfa leafcutting bee.

\section{MATERIALS AND METHODS}

Our Research Centre was given 1400 prepupae in 1981 and 1620 in 1982 from Kompolt (NorthHungary) from the imported stock for experimental purposes.

The number of parasites is followed in the relevant literature only until the emergence of bees (HosBs, 1968). The principal objective of our tests in 1981 was to determine the infestation rate of cocoons of emerged bees by Melittobia acasta Walker. In 1982 our aim was to count the total number of parasites during the emergence period.

The prepupae were held in Kompolt at $0-1{ }^{\circ} \mathrm{C}$ for one month in an attempt to kill 96 per cent of the parasites. Before incubation t:.2 prepupae were treated with a solution of Carbaryl $(0.2 \%)$, aiming at 98 per cent mortality of the parasites.

In 1981 the 1400 emerging bees were placed in alfalfa fields (variety Tápiószelei-1) in Dömsöd (Middie-Hungary) after being treated with Carbaryl and incubated.

1200 cocoons left by hosts were carried from the field to the laboratory and kept in polyethylene bags at $21^{\circ} \mathrm{C}$ and 70 per cent R.H. for 50 days. The number of newly emerged parasites was reco: ded every day.

The lifespan of adult Melittobia was examined in groups of 3 kept loosely and in groups of 96 and 106 kept jam tight in test-tubes, under the same environmental conditions, without food. 
The mobility of Melittobia was examined between 23 and 30 July 1981 under similar microclimatic conditions, by randomly choosing 1.4 and 100 females per group, respectively. The movement of the adults towards day-light was followed by drawing it on a piece of $1 \mathrm{~m}$ wide cardboard and recording the time.

In 1982 we were given 1620 overwintered cocoons. One part was treated with chemicals, the other part was used as an untreated control.

The groups were incubated in four different places at $28^{\circ} \mathrm{C}$, according to a rotational plan (Fig. 1).

We succeeded in making good quality radiographs of the prepupae with the MAMMOMAT (GDR) TUR D 240 automatic radiographic apparatus.

Instead of the usual glass vials, paper and polyethylene bags or paper-polyethylene and metal boxes, we used bags of finer texture silk-sieve, used in the milling industry, to separate the several groups.

\section{RESULTS}

1.1. Contrary to the well known and applied control methods, the emergence rate of alfalfa leafcutting bees was very poor in 1981 (26.3 per cent). This high mortality rate was caused by $M$. acasta contamination of 48.6 per cent ; 24.8 per cent of the bees perished as larvae, prepupae or adults and 0.3 per cent were infested with chalkbrood. Under the described conditions, i.e. during 50 days after the completion of emergence, one male leafcutting bee and 4913 Melittobia emerged from the 1200 alfalfa leafcutting bee cocoons.

1.2. Under crowded conditions the Melittobia groups kept without food perished in 14 (14-28 September) and 10 (18-28 September) days, respectively. In another treatment 33 per cent of the loosely kept and 56 and 62 per cent of the crowded groups, respectively, perished in 13 days.

1.3. The first Melittobia chosen randomly covered a distance of $28.55 \mathrm{~m}$ during the three days between 23 and 25 July (it was made to run for an hour every day). It made a total of 130 small jumps, 93 the first, 19 the second and 18 the third day.

The four females made to run on the next occasion exceeded the first female by a velocity of 9.3-14.4 m/hour. The directions of motion and traces of these four females and those of individuals from the third group of 100 were so similar that they could hardly be distinguished form one another.

2.1. In 1982 we examined 57 per cent of the 1620 incubated preppuae, i.e. 930 individuals by $x$-rays once, 263 prepuae were examined twice and 66 three times (Fig. 1). The first group was radiographed on the 12th and 19th ; the second group on the 7 th, 14 th and 21 st ; the third group on the 0 th, 7 th and 
14th; and the fourth group on the 3rd and 10th day of emergence. The content of the unopened cocoons could be examined by this method. We found that 9 per cent of the overwintered prepupae contained small larvae, 39 per cent large larvae and 27 per cent 37 per cent of the prepupae were infested with parasites.

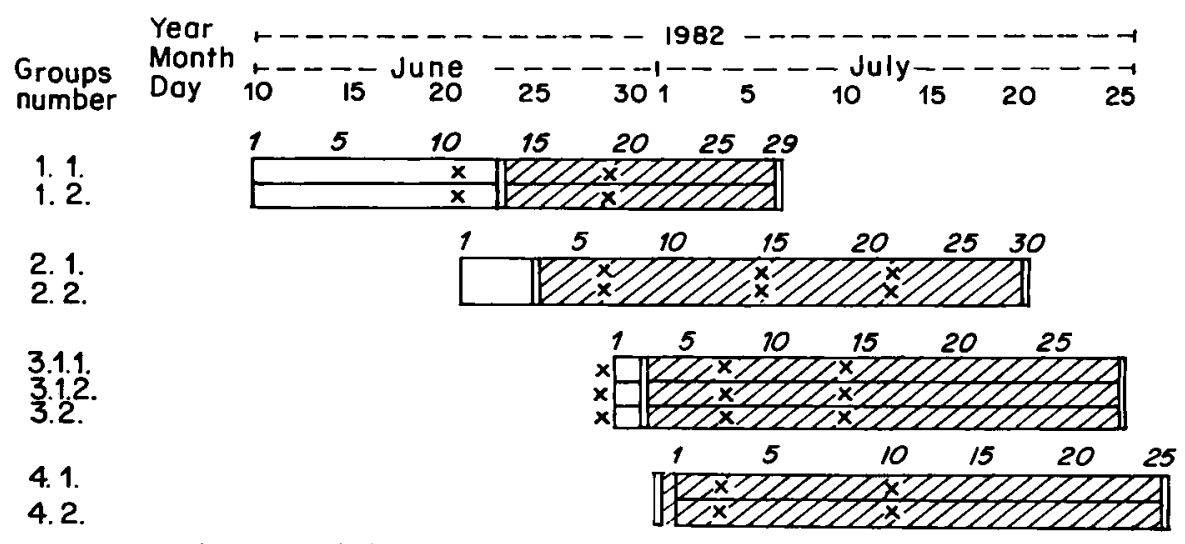

Explanation of signs:

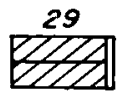

day of incubation period of emergence of parasites

$x$ day of $x$-radiography

FIG. 1. - Incubation of Megachile rotundata and x-radiography of prepupae (groups 1-4)

TABL. 1. - Number and percentage of alfalfa leafcutting bees and parasites emerged from one leafcutting bee stock at different times (GöböLlö, 1982)

\begin{tabular}{|c|c|c|c|c|c|}
\hline Nr. of treatments & $\begin{array}{c}\mathrm{Nr} \text {. of } \\
\text { prepupae }\end{array}$ & Migachile & Coelioxys & Melittobia & $\begin{array}{c}\text { Parasites } \\
\text { total }\end{array}$ \\
\hline 1.1. & 55 & 33 & 6 & 192 & 198 \\
\hline 2.1 & 250 & 31 & 14 & 430 & 444 \\
\hline 3.1 .1 . & 250 & 44 & 32 & 833 & 865 \\
\hline 4.1. & 250 & 12 & 15 & 194 & 209 \\
\hline Treated total & 805 & 120 & 67 & 1649 & 1716 \\
\hline 1.2. & 65 & 11 & 5 & 316 & 321 \\
\hline 2.2 . & 250 & 4 & 2 & 1935 & 1937 \\
\hline 3.2. & 125 & 3 & 1 & 640 & 641 \\
\hline 4.2 & 250 & 5 & 13 & 1674 & 1687 \\
\hline Control total & 690 & 23 & 21 & 4565 & 4586 \\
\hline Control + treated total & 1495 & 143 & 88 & 6214 & 6302 \\
\hline 3.1.2. treated & 125 & 8 & 4 & 649 & 653 \\
\hline Total & 1620 & 151 & 92 & 6863 & 6955 \\
\hline
\end{tabular}


2.2. In the four groups of stock, 7106 insects emerged from the total of 1620 cocoons (Table 1) during four consecutive periods. Besides the 151 (9.3 per cent) alfalfa leafcutting bees, two dangerous hymenopteran parasites also emerged : 92 (5.7 per cent) Coelioxys rufocaudata Smith (Megachilidae) and 6863 Melittobia acasta (Eulophidae).

2.3. According to the evaluation of data collected, the treatment with Sevin increased not only the emergence rate of leafcutting bees, but also that of Coelioxys rufocaudata. Comparing the emergence rate of the treated groups to the control, five times more (120) Megachile and three times more (67) Coelioxys emerged from the cocoons ; while the 1649 Melittobia were one third of the individuals of the control group.

The highest number of Melittobia emerged between the 6th and 10 th days of incubation in the treated groups and between the 16 th and 20 th days in the control ones, respectively (Table 2).

TABL. 2. - Number of alfalfa leafcutting bees and parasites emerged from the 1.2-4.1 treated and 1.2-4.2 untreated groups (GöDöLlö, 1982)

\begin{tabular}{|c|c|c|c|c|c|c|c|c|c|c|c|c|}
\hline \multirow{4}{*}{$\begin{array}{c}\text { Date } \\
\text { of emergence }\end{array}$} & \multicolumn{2}{|c|}{ Megachile } & \multicolumn{2}{|c|}{ Coelioxys } & \multicolumn{2}{|c|}{ Melittobia } & \multicolumn{2}{|c|}{ Megachile } & \multicolumn{2}{|c|}{ Coelioxys } & \multicolumn{2}{|c|}{ Melittobia } \\
\hline & \multicolumn{12}{|c|}{ emerged from } \\
\hline & \multicolumn{6}{|c|}{$\begin{array}{l}805-270 \text { containing pollen } \\
=506 \text { treated cocoons }\end{array}$} & \multicolumn{6}{|c|}{$\begin{array}{l}690-180 \text { containing pollen } \\
=506 \text { untreated cocoons }\end{array}$} \\
\hline & $\mathrm{Nr}$ & $\%$ & $\mathrm{Nr}$ & $\%$ & $\mathrm{Nr}$ & $\%$ & $\mathrm{Nr}$ & $\%$ & $\mathrm{Nr}$ & $\%$ & $\mathrm{Nr}$ & $\%$ \\
\hline $1-5$ & - & - & - & - & 48 & 3 & - & - & - & - & 113 & 2 \\
\hline $6-10$ & 8 & 7 & 1 & 1 & 583 & 35 & 3 & 13 & 4 & 19 & 305 & 7 \\
\hline $11-15$ & 13 & 11 & - & - & 289 & 18 & 2 & 9 & - & - & 788 & 17 \\
\hline $16-20$ & 37 & 31 & 29 & 43 & 190 & 12 & 2 & 9 & 8 & 38 & 2591 & 57 \\
\hline $21-25$ & 47 & 39 & 30 & 45 & 345 & 21 & 1 & 5 & 2 & 9 & 589 & 13 \\
\hline $26-30$ & 15 & 12 & 2 & 3 & 153 & 9 & 4 & 18 & 2 & 9 & 160 & 3 \\
\hline $31-40$ & & & 5 & 8 & 41 & 2 & 11 & 46 & 5 & 25 & 19 & 1 \\
\hline Total & 120 & 100 & 67 & 100 & 1649 & 100 & 23 & 100 & 21 & 100 & 4565 & 100 \\
\hline
\end{tabular}

2.4. 1620 prepupae were investigated by x-radiography. 31 per cent of them contained only pollen, or pollen, nectar and dead eggs. This result is similar to that of New Zealand leafcutting bees (READ and Donovan, 1980). 


\section{DISCUSSION AND CONCLUSION}

1. The motion of all Melittobia acasta insects tends towards day-light. Those leaving the strip of paper sideways took a longer time to make the shorter distance than the ones moving towards light. Owing to its lifespan and mobility, this species is able to travel further than previously supposed.

2. It will be possible in the future using x-radiography, to determine the stage of development of prepupae before storage in a refrigerator for the winter period, in order to choose the right time of cooling.

3. The radiographs taken are of very good quality, even the species of parasites can be determined, e.g. Coelioxys spp. can be distinguished from Megachile and the propagation of Chalcidoidea can also be followed.

TARL. 3. - Quality of treated and untreated groups at the beginning and the end of incubation (GöDöLLö, 1982)

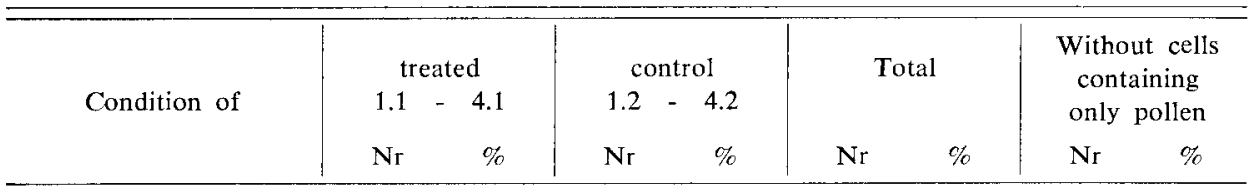

Groups 1.-4. at the first $\mathrm{x}$-radiography control on the 5th day of incubation

\begin{tabular}{l|rr|rr|rr|rr} 
Cont. pollen & 129 & 33 & 79 & 32 & 208 & 33 & - & - \\
Small larvae & 38 & 10 & 13 & 5 & 51 & 8 & 51 & 12 \\
Large larvae & 98 & 27 & 88 & 34 & 186 & 32 & 186 & 43 \\
Pupae & 73 & 23 & 13 & 5 & 86 & 13 & 86 & 21 \\
Parasites & 27 & 7 & 62 & 24 & 89 & 14 & 89 & 24 \\
Total & 365 & 100 & 255 & 100 & 620 & 100 & 412 & 100 \\
\hline
\end{tabular}

Groups 1.-4. at the last x-radiography control on the 16 th day of incubation

\begin{tabular}{l|rr|rr|rr|rr} 
Cont. pollen & 67 & 29 & 25 & 20 & 92 & 26 & - & - \\
Small larvae & 9 & 4 & 4 & 3 & 13 & 4 & 13 & 5 \\
Large larvae & 23 & 10 & 21 & 17 & 44 & 12 & 44 & 17 \\
Pupae & 81 & 36 & 5 & 4 & 86 & 25 & 86 & 33 \\
Parasites & 47 & 21 & 67 & 56 & 114 & 33 & 114 & 45 \\
Total & 227 & 100 & 122 & 100 & 349 & 100 & 257 & 100 \\
\hline
\end{tabular}

Difference in percentage

Cont. pollen

Small larvae

Large larvae

Puppae

Parasites

\begin{tabular}{r|r|}
-4 & -12 \\
-6 & -2 \\
-17 & -17 \\
+13 & -1 \\
+14 & +22
\end{tabular}

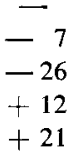


Parasitism could be determined the day before $(0)$ emergence by $\mathrm{x}$-radiography. In the nine groups of the four stocks investigated - without the cocoons containing only pollen - 24 per cent of the prepupae were infested by parasites at the time of the first radiography on the 5 th day and 45 per cent of them were infested at the time of the last $\mathrm{x}$-radiography on the 16th day (Table 3).

It was possible to compare the rate of development of the host and its two most important parasites during the emergence period.

3.1. Melittobia acasta is a polyvoltine species. Its development is rapid and seems to be independent of the number of emergence days. Some Melittobia adults appeared even on the second day of emergence from the leafcutting bee cocoons stored at lower temperatures. These adults can reinfest the same Megachile stock. It can be seen on the x-radiographs taken at different stages of emergence (Table 3), that the development of small and large larvae and prepupae is irregular.

This is due to the parasitism caused by a new larval generation. The degree of infestation is dependent upon the applied treatment method.

This second $M$. acasta generation emerges after the emergence of alfalfa leafcutting bees, and its emergence can take up to 50 days. This generation starts from the cocoons left behind at the nesting place and infests the newer, young larvae of the host.

3.2. Coelioxys rufocaudata is a univoltine species. According to our records taken from 23 June to 23 July 1982 the Coelioxys emerges after the emergence of male leafcutting bees, together with Megachile females. Its emergence culminated after the swarming period of the host. Sporadic appearence of some Coelioxys females was also observed after 26 July. This can be explained by the fact that Coelioxys needs the open leafcutting bee cells instead of new larvae for starting its new generation.

4. The damages caused by the two parasites has rendered the stocks unsuitable for maintenance. New stocks should be imported and new technological management tools must be introduced, in addition to currently available methods, to achieve reduction in infestations.

5. It is advisable to make test incubations every year in order to determine the hygienic state of the stocks propagated at several places. The determination of sex ratio is also of great importance.

6. The quality of the stock can be determined by $x$-radiography. 


\section{RESUME \\ IUUTE CONTRE LES INSECTES PARASITES DE LA SOUCHE DE MEGACHILES, MEGACHILE ROTUNDATA FABR.}

Des millions de prénymphes de Megachile rotundata ont été importées des Etats-Unis en Hongrie entre 1972 et 1978, mais l'introduction généralisée de cette abeille en Hongrie, prévue pour 1974 et 1975, n’a pu être réalisée en raison du parasitisme élevé. La situation nous a conduit à rechercher les possibilités d'une propagation artificielle et des méthodes pour lutter contre les parasites. Notre Centre de recherches a reçu pour ses expériences 1400 prénymphes en 1981 et 1620 en 1982 du stock importé.

En 1981 nous avons déterminé l'infestation des cocons par Melittobia acasta Walker après émergence de $M$. rotundata. En 1982 nous avons dénombré les parasites qui ont éclos durant la période d'incubation de l'hôte. En 1981 et 1982 les prénymphes ont été conservées à Kompolt durant l'hiver pendant un mois à $0-1{ }^{\circ} \mathrm{C}$ et traitées avant la période d'incubation au carbaryl à $0,2 \%$. En 1981 on a installé dans des champs de luzerne (variété Tapiószelei-1) à Dömsöd (Hongrie centrale) 1400 mégachiles naissantes après traitement au carbaryl et incubation. 1200 cocons laissés par les hôtes ont été transportés des champs au laboratoire et conservés dans des sacs de polyéthylène à $21^{\circ} \mathrm{C}$ et $70 \%$ HR pendant 50 jours. Des ces 1200 cocons de mégachiles ont éclos un mégachile mâle et 4913 Melitiobia. Les Melittobia adultes se sont déplacés vers la lumière du jour à la vitesse de $9-14 \mathrm{~m} / \mathrm{h}$; ils sont morts dans les 14 jours suivants par absence de nourriture.

En 1982 on a reçu 4 groupes de prénymphes ayant hiverné. Une partie des cocons fut traitée avec des produits chimiques. On a traité un groupe avec du Sevin à $2 \%$ en lavant les nymphes, au lieu de les laisser quelques jours dans la solution, selon la méthode habituelle. On a examiné $57 \%$ des 1620 prénymphes incubées : 930 individus ont été radiographiés une fois, 263 deux fois et 66 trois fois. Sur l'ensemble des 1620 cocons des 4 groupes, 7106 insectes ont éclos, se répartissant en $151(9,3 \%)$ mégachiles et 2 dangereux hyménoptères parasites : $92(5,7 \%)$ Coelioxys rufocaudata Smith (Megachilidae) et 6863 (Melittobia acasta Walker (Eulophidae). Selon l'évaluation des données récoltées, le traitement au Sevin a accru non seulement le taux d'émergence des mégachiles, mais aussi celui de Coelioxys rufocaudata.

En comparant le taux d'émergence des groupes traités et du groupe témoin on s'aperçoit que 5 fois plus de mégachiles (120) et 3 fois plus de Coelioxys (67) ont éclos des cocons, tandis que les 1649 Melitobia représentent $1 / 3$ des individus du groupe témoin. Les populations de mégachiles importées des Etats-Unis ont été conservées à des températures inférieures et traitées avec des insecticides à base de carbaryl (par exemple Sevin) durant l'incubation réalisée à grande échelle. Des pièges lumineux ont également été utilisés pour tuer les parasites mais ils ne pouvaient que capturer des adultes en vol. Malgré ces méthodes de lutte, des parasites ont survécu et infesté la descendance. Le déplacement des cocons à $4 \mathrm{~m}$ du site de nidification - selon les recommandations de NémETH, 1981 - n'offre pas de protection fiable contre de tels parasites, puisqu'ils sont capables de ramper sur une distance de $100 \mathrm{~m}$, comme l'ont montré nos tests.

Melittobia peut rester dangereux malgré les opérations de lutte menées jusqu'à présent. Son éclosion protégée, sa durée de vie relativement longue et sa grande mobilité peuvent aboutir non seulement à une réinfestation mais causer aussi des dégâts à d'autres hyménoptères pollinisateurs de la luzerne.

Coelioxys était considéré comme un parasite rare en Hongrie (Fauna Hungariae, 1958, vol. 12, $\mathbf{n}^{0}$ 12), mais il s'est maintenant propagé et étendu à de nouvelles régions parallèlement à l'introduction de la mégachile sur une grande échelle.

Les dégâts causés par les deux parasites ont rendu les souches impropres à leur maintien. I1 faudrait en importer de nouvelles et introduire de nouvelles techniques d'élevage, en plus des méthodes déjà disponibles, pour parvenir à réduire les infestations. 


\title{
ZUSAMMENFASSUNG
}

\author{
BEKAMPFUNG PARASITISCHER INSEKTEN \\ DER LUZERNE-BLATTSCHNEIDEBIENE, MEGACHILE ROTUNDATA FABR.
}

Zwischen 1972 und 1978 wurden Millionen von Vorpuppen aus den USA nach Ungarn importiert, aber der für 1974 und 1975 geplante allgemeine Import der Luzerne-Blattschneidebiene Megachile rotundate Fabricius konnte wegen schwerer Parasitierung nicht durchgeführt werden. Diese Situation veranlaßte uns, die Möglichkeiten einer künstlichen Vermehrung und Methoden einer Kontrolle der Parasiten der Blattschneidebienen zu untersuchen. Unsere Forschungsstation hat im Jahre 1981 etwa 1400 Puppen und 19821620 Puppen aus dem importierten Bestand erhalten.

1981 bestimmten wir aus leeren Kokons der geschlüpften Blattschneidebienen den Befall mit Mellittobia acasta Walker. Im Jahre 1982 zählten wir alle Parasiten, die während der Inkubationszeit ausschlüpften. 1981 und 1982 wurden die Vorpuppen im Winter für einen Monat in Kompolt bei einer Temperatur von $0-1{ }^{\circ} \mathrm{C}$ gehalten. Vor der Inkubation wurden sie mit $0,2 \%$ Carbaryl behandelt. 1981 wurden 1400 schlüpfende Bienen in Luzernefeldern (Varietät Tápiószelei-l) in Dömsöd, Mittelungarn nach Behandlung mit Carbaryl und Inkubation ausgesetzt.

Diese Wirtstiere lieferten 1200 Kokons, die in das Laboratorium gebracht und in Plastikbeuteln bei einer Temperatur von $21^{\circ} \mathrm{C}$ und $70 \%$ r.F. für 50 Tage gehalten wurden. Aus diesen 1200 Kokons der Luzerne-Blattschneidebiene schlüpften eine männliche Blattschneidebiene und 4913 Individuen von Melittobia. Die Melittobia-Tiere bewegten sich mit einer Geschwindigkeit von $9-14 \mathrm{~m} / \mathrm{h}$ gegen das Tageslicht; sie gingen ohne Futter innerhalb von 14 Tagen ein.

1982 erhielten wir vier verschiedene Gruppen überwinterter Vorpuppen. Ein Teil der Kokons wurde mit Chemikalien behandelt. Eine Gruppe wurde von uns mit $0,2 \%$ Sevin behandelt, aber nicht wie üblich durch Eintauchen in die Lösung für mehrere Minuten, sondern durch Waschen. $57 \%$ der 1620 inkubierten Vorpuppen untersuchten wir 1-3 mal mit Röntgenstrahlen. Aus der Gesamtzahl dieser 1620 Kokons der vier Gruppen schlüpften 7106 Insekten : $151(=9,3 \%)$ waren Blattschneidebeinen, $92(=5,7 \%)$ Coelioxys rufocaudata Smith (Megachilidae) und 6863 Melittobia acasta Walker (Eulophidae), beides gefährliche parasitische Hymenopteren.

Nach den vorliegenden Daten erhöhte die Behandlung mit Sevin nicht nur die Schlüpfrate der Blattschneidebiene, sondern auch die von Coelioxys rufocaudata. Es schlüpften fünf mal mehr Megachile (120) und drei mal mehr Coelioxys (67), während die Zahl der Melittobia mit 1649 nur ein Drittel der Tiere der Kontrollgruppe betrug.

Aus den USA nach Ungarn importierten Populationen der Luzerne-Blattschneidebiene wurden während der Überwinterung bei niedrigeren Temperaturen gehalten und während der im großen Maßstab durchgeführten Inkubation mit carbarylhältigen Insektiziden (z.B. Sevin) behandelt. Es wurde auch versucht, Parasiten mit Hilfe von Lichtfallen zu töten, aber damit konnten natürlich nur adulte Tiere erreicht werden. Trotz dieser Bekämpfungsmaßnahmen sind Parasiten übriggeblieben und es kam zu einem Befall der Nachkommenschaft. Die Verbringung der Kokons bis in eine Entfernung von $4 \mathrm{~m}$ vom Nistplatz, entsprechend den technischen Empfehlungen von NEMETH, 1981, bietet gegen diese Parasiten auch keinen Schutz, da sie nach unseren Ergebnissen bis $100 \mathrm{~m}$ weit kriechen können.

Melittobia könnte trotz aller bisher durchgeführten Bekämpfungsmaßnahmen gefährlich bleiben. Der geschützte Ausschlupf, die relativ lange Lebensdauer und die große Beweglichkeit des Parasiten können nicht nur zur Reinfektion, sondern auch zu Schäden bei anderen Hymenopteren unter den Bestäubern der Luzerne führen.

Coelioxys war bisher für Ungarn als relativ seltener Parasit bekannt (Fauna Hungarica, 1958, Vol. XII. Nr. 12), aber gegenwärtig nimmt er zu und breitet er sich in neue Gebiete zusammen mit der im großen betriebenen Einführung von Blattschneidebienen der Lunzerne aus. 
Die durch die beiden Parasiten verursachten Schäden haben die Weiterführung der Stämme zwecklos gemacht. Neue Stämme sollten importiert werden, zusammen mit neuen Technologien ihrer Zucht, zusätzlich zu den schon vorhandenen Methoden, um eine Verringerung des Befalls zu erreichen.

\section{BIBLIOGRAPHY}

BoHART G.E., 1962. - How to manage the alfalfa leaf cutting bee (Megachile rotundata Fabr.) for alfalfa pollination. Agr. Exp. Str., Utah State University, 7 p.

Hoвbs G.A., 1968. - Controlling insect enemies of the alfalfa leafcutter bee, Megachile rotundata. Can. Entomol., 100, 781-784.

Holm S.V. N., 1982. - Management of Megachile rotundata for pollination of seed crops in Denmark. Proc. 1st int. Symp. on Alfalfa Leafcutter Bee Management, Saskatoon, Canada, 223-233.

Krunic M.D., Hinks C.F., 1972. - The Effect of temperature and of temperature pretreatment on diapause and on the synchronization of adult emergence in Megachile rotundaia (Hym., Megachilidae). Can. Entomol., 104, 889-893.

Manninger S., 1970. - A lucerna szabóméh (Megachile rotundata F.) biológiája és várható jelentósége a lucerna magtermesztésének fejlesztéséért [Biology of alfalfa leafcutter bee, Megachile rotundata $F$. and its future importance in alfalfa seed production of Hungary] in : Mándy-Virányi. A herefélék termesztésének fejlesztéséért, Budapest, Mg. Kiadó.

Móczar L., Böjtös Z., 1957. - A lucernát megporzó méhfélék [Apoidea pollinating alfalfa]. MTA. Agr. Tud. O. Közleményei, 13, 148-178.

Morgner F., 1973. - Aufzucht von Hummelvölkern (Bombus spp.) und Blattschneiderbienen (Megachile rotundata) und ihr Einsatz zur Bestäubung kleiner Vermehrungseinheiten. Zeitschrift für Pflanzenzücht., 70, 246-292.

NÉMETH J., 1978. - A lucerna szabóméh Megachile rotundata F. térbeli orientációjának vizsgálata [Orientation of alfalfa leafcutter bees, Megachile rotundata F. in space]. GATE Mezógazdasági Tudományi Kar Allattani Tanszék, 32 p.

Rank G.H., Goerzen D.W., 1981. - Native leafcutter bee species and associated parasites in commercial hives in Saskatchewan, Canada. Apidologie, 12, 211-220.

Read P.E.C., Donovan B.I., 1980. - Leafcutting bee life history allocation detailes and management techniques. Entomol. Div. DSIR Lincoln, Sud. Ed. Rev. 24.

RichardS K.W., 1982. - Inputs, expectations and management of the alfalfa leafcutter bee, Megachile rotundata, Proc. of 1st Int. Symp. on Alfalfa Leafcutter Bee Management, Saskatoon, Canada, 113-135.

STEPhen W.P., 1961. - Artificial nesting sites for the propagation of the leafcutter bee, Megachile (Eutricharea) rotundata for alfalfa pollination. Econ. Entomol., 54, 989-993.

StePheN W.P., Undurraga J.M., 1976. - X-Radiography, an analytical tool in population studies of the leafcutter bee Megachile pacifica (= rotundata). J. Apic. Res., 15, 81-87. 